\title{
Pigmented paravenous retinochoroidal atrophy
}

INSERM

\section{Source}

INSERM. (1999). Orphanet: an online rare disease and orphan drug data base. Pigmented paravenous retinochoroidal atrophy. ORPHA:251295

Pigmented paravenous retinochoroidal atrophy (PPRCA) is a rare, commonly bilateral and symmetric retinal disease characterized by non-progressive or slowly progressive chorioretinal atrophy, peripapillary pigmentary changes and accumulation of "bonecorpuscle" pigmentation along the retinal veins and which is usually asymptomatic or can present with mild blurred vision. 